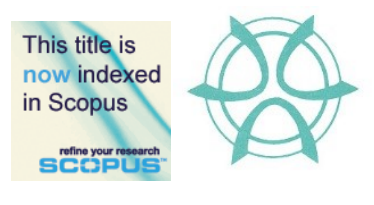

\title{
THE MATRIX OF LAND TENURE PROPERTY RIGHT FOR WATER SETTLEMENT AREA
}

\author{
Farah Zaini ${ }^{1}$, Shyafiena Abdul Aziz $^{2}$, Nurlaila Ali ${ }^{3}$, Adibah Yusuf ${ }^{4}$ \\ ${ }^{1,2,4}$ Faculty of Social Sciences and Humanities \\ UNIVERSITI MALAYSIA SARAWAK \\ ${ }^{3}$ Land Branch, \\ LAND AND SURVEY DEPARTMENT, SARAWAK
}

\begin{abstract}
The Land Tenure Property Right (LTPR) concept is critical for establishing ownership and rights to land or property. Land is inextricably linked to a community's social identities, and it is critical for them to understand their rights. Water settlement areas are not included in the formal LTPR, which results in ambiguous rights, informal land tenure, and ambiguity regarding certain LTPR elements. As a result, this article will discuss the difficulties associated with LTPR in this area. The article employs a qualitative approach, with data collected via face-to-face interviews and analysed using thematic analysis. Three case studies are included, in which all of the villages are located in a water settlement area. Six challenges are identified in the context of LTPR that require revision and strengthening. By combining the general LTPR framework and the results, a Matrix of LTPR that meets the criteria in the water settlement area is produced.
\end{abstract}

Keywords: land tenure, property right, water settlement area, qualitative study

\footnotetext{
${ }^{1}$ Lecturer at Universiti Malaysia Sarawak. Email: zfarah@unimas.my
} 


\section{INTRODUCTION}

Land tenure and property rights refer to the interests that individuals, communities, families, businesses, and other corporate or community structures have in land, water, forestry, wildlife, and, in some cases, mineral resources. According to a 2013 report by USAID, private ownership, leasehold, and various types of corporate rights, such as community, group, and shareholder, are all examples of property rights and tenure arrangements. Systematic property rights include mechanisms for resolving disputes, defending rights, and administering or managing land-based resources.

There is mounting evidence that tenure and property rights issues can contribute significantly to political instability, population displacement, food insecurity, and environmental degradation, undermining or preventing the successful implementation of development programs (Courtney et. al., 2017). The issue of land tenure and property rights encompasses both terrestrial and subterranean land, as well as marine space. In Sarawak, there are a few traditional fisherman villages located on the water (water village) where small-scale fisheries provide the primary source of income. The community's pattern of life in the water settlement area is similar to most other Malay communities. They want to live in close proximity to one another; also, a parcel of land with numerous dwellings is occupied by family members such as siblings or relatives (Samsudin \& Abidin, 2016). Frequently, those who live in water settlement areas are vulnerable because their land tenure is not legally recognised; additionally, they face threats posed by climate change. Vulnerability is the impediment to attaining sustainable development (Ismail et. al., 2019).

Proper land tenure and property rights will result in best land use practices (Samsudin, 2020). The best land use practices can help protect or improve the state of the environment, or vice versa. Simultaneously, ambiguous land policies, insecurity of tenure, lack of clear rights, and lack of coordination regarding land use will have an effect on the environment and natural resources (FAO, 2002). As a result, it is a major concern; if formal land tenure is absent in the area, the issue of land title insecurity may arise.

Thus, this article discusses the Land Tenure Property Right (LTPR) concept, the LTPR issue, and how the concept aids in defining the LTPR for water settlement areas.

\section{LAND TENURE AND PROPERTY RIGHT}

Land tenure, land value, land use, and land development are the four primary functions of the modern land administration system. The four functions are interdependent and cannot exist independently. Each of these functions complements the other in the land administration organisation. According to Williamson et al. (2010), land value is influenced by the economic and physical use of land. Additionally, land zoning and planning guidelines and regulations 
Farah Zaini, Shyafiena Abdul Aziz, Nurlaila Ali, Nurul Huda Marwab

The Matrix of Land Tenure Property Right for Water Settlement Area

have an effect on the land's value. Meanwhile, land use planning and policies determine the concept of future land development.

The National Land Code (Act 828), the Sarawak Land Code (Cap 81), and the Sabah Land Ordinance (Cap 68) govern the land administration system in Malaysia.

\section{Land Tenure}

Land tenure can be defined as an institution in which rules and guidelines are established to regulate how public land is used. The rules governing access to grant permission or rights to use, control, and transfer land titles include the associated responsibilities and restrictions. In simple terms, the land tenure system aids in determining who is eligible to utilise a land resource based on the time and condition of the resource (FAO, 2002). According to the United Nations Economic Commission for Europe (2005), land tenure is 'the mode of acquiring land rights. Land tenure is defined as the nature and manner in which rights and interests can be created, transferred, and retained through the various types of land (AUC, ECA, \& AfDB., 2010).

Land tenure is determined by four distinct processes: statutory, customary, religious, and informal. All four of these factors will influence land use, development type, and other land transactions (Payne et al., 2015). Additionally, within the same country, various types of land tenure exist. It varies according to the type of development and the policies that support it. For example, statutory law is more commonly associated with urban areas, whereas customary law is prevalent in rural areas. This circumstance has exacerbated conflicts over land administration and development objectives.

\section{Property Right}

Denise (2007) concurs that the modern legal concept of property ownership is referred to as a bundle of rights. Essentially, the term 'bundle' derives from the root word 'bind' or 'binding'. The term 'bundle' refers to the collection of items that were previously separate and existed independently (Fischel, 2009). In practice, multiple individuals or groups may hold various rights, such as the right to sell the land, the right to use the land, or the right of way across the land. For example, the bundle of rights, or as some refer to it, the sticks in the bundle, may be shared between a landowner and a tenant in order to form a leasing agreement. Each party retains all rights resulting from the agreement (FAO, 2002).

Property rights can be defined as a collection of rights to use, control, and transfer assets, including land. Property rights are social conventions that reflect people's agreement on how to hold, use, and exchange these assets. These include the rights to occupy, enjoy, and use land; to exclude others from entering or using land; to dispose, buy, or inherit land; to develop or improve land; to 
cultivate land; to sublet land; to realise financial benefits; and to access landrelated services (USAID, 2013).

\section{The Concept of Land Tenure Property Right (LTPR)}

USAID published a Land Tenure Property Right framework in 2013 that addressed four areas: knowledge management, training and capacity development, LTPR issues and situation assessment, and LTPR intervention and impact assessment. This framework is intended to aid in the comprehension of LTPR. The framework is depicted in Figure 1.

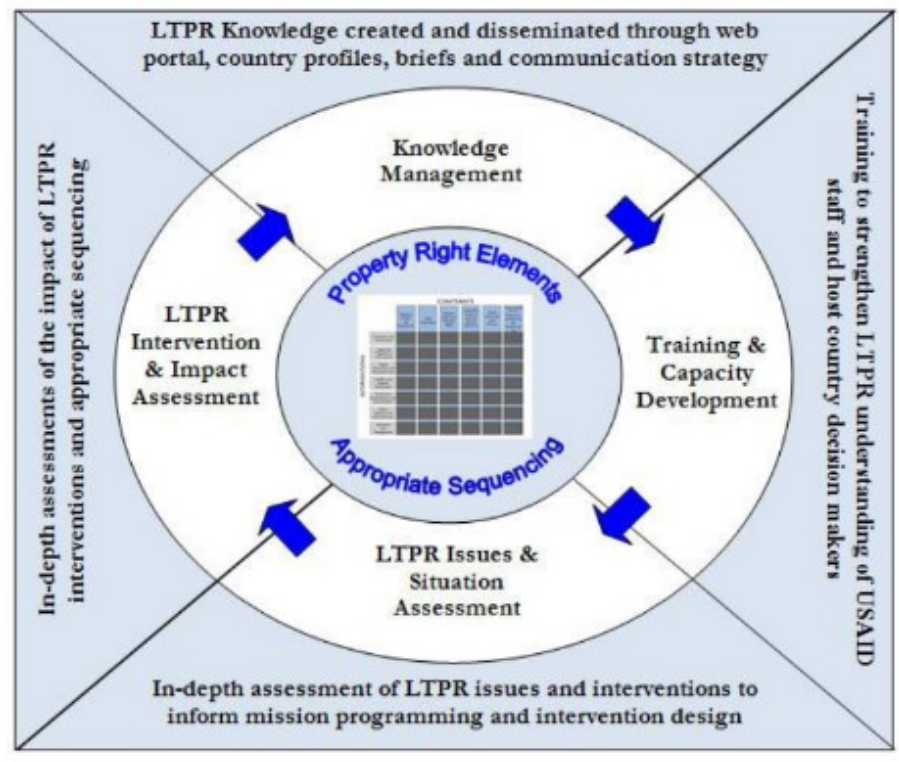

Figure 1: The Framework of Land Tenure Property Right Source: USAID, 2013

Six constraints and common sub issues were discussed throughout the framework as in Table 1: 
Farah Zaini, Shyafiena Abdul Aziz, Nurlaila Ali, Nurul Huda Marwab

The Matrix of Land Tenure Property Right for Water Settlement Area

Table 1: Common Sub Issues for LTPR

\begin{tabular}{cl}
\hline \multicolumn{1}{c}{ Issues } & \multicolumn{1}{c}{ Description } \\
\hline Resource conflict and displacement & It encompasses conflict over land and \\
& resource inequity, tenure insecurity as a \\
result of competition, and land grabbing.
\end{tabular}

$\begin{array}{ll}\text { Weak Governance } & \text { It entails a lack of transparency, as well as } \\ & \text { a variety of statutory, customary, and } \\ \text { informal tenure systems. }\end{array}$

Insecure tenure and property rights Tenure and property rights insecurity encompasses land disputes, informal settlements, a lack of infrastructure development, and insecure tenure for vulnerable groups.

\begin{tabular}{ll}
$\begin{array}{l}\text { Inequitable access to land and natural } \\
\text { resources }\end{array}$ & $\begin{array}{l}\text { This constraint applies to landlessness, } \\
\text { displacement, natural disasters, and } \\
\text { informal urban settlements. }\end{array}$ \\
\hline Poorly performing land markets & $\begin{array}{l}\text { This includes inaccuracies/absence of } \\
\text { market data and the growth of unplanned } \\
\text { development. }\end{array}$
\end{tabular}

Unsustainable natural resource management and biodiversity loss

It encompasses insecurity, ill-defined, and insufficient land rights.

Sources: USAID (2013)

\section{METHODOLOGY}

This article employs a qualitative research methodology. Furthermore, this study highlighted the findings based on information gathered from community leaders (head of village) only. Thus, three community leaders were interviewed face to face in three different case studies. Thematic analysis was used to analyse these data. This research will focus on three villages: Kampung Seberang Kedai and Kampung Limpaku Pinang in Limbang, and Kampung Awat-awat in Lawas. These villages were chosen because they are located in a water settlement area in Sarawak, thus meeting the study's criteria. The elements of land tenure property rights for water settlement areas were derived in the form of a matrix for LTPR based on the results of the interview with the respondent. The acronyms for each of the three villages mentioned in this article are listed in Table 2. 
Table 2: Acronyms for Respondents

\begin{tabular}{ll}
\hline & Acronym \\
\hline $\begin{array}{l}\text { Kampung Limpaku Pinang, Limbang, } \\
\text { Sarawak }\end{array}$ & \\
\hline $\begin{array}{l}\text { Kampung Seberang Kedai, Limbang, } \\
\text { Sarawak }\end{array}$ & \\
\hline $\begin{array}{l}\text { Kampung Bangsal, Awat-Awat, Lawas } \\
\text { Sarawak }\end{array}$ & R3 \\
\hline
\end{tabular}

\section{THE CHALLENGES OF LTPR FOR WATER SETTLEMENT AREA}

Six (6) challenges of LTPR in the water settlement area have been identified through thematic analyses. While these three case studies are geographically distinct, their issues and challenges regarding land tenure and property rights are similar. The results are summarised in Figure 2.

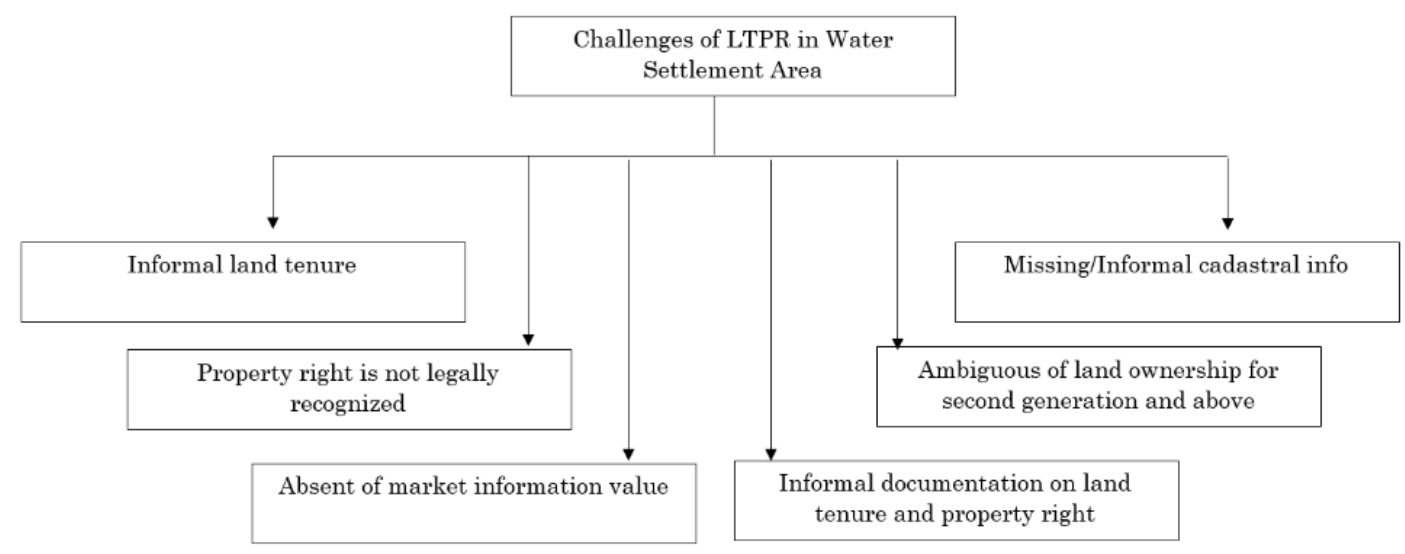

Figure 2: Challenges of LTPR in Water Settlement Area

\section{Challenge 1: Informal Land Tenure}

Land tenure in the case studies is based on informal systems of tenure. According to R1 and R3, these villages have informal land titles and possess the area on a 'first come, first served' basis. In contrast to R2, the village has two distinct titles: formal and informal. Typically, the first generation receives the formal title, but not the second. In this village, informal land tenure contributes to tenure insecurity, particularly for those classified as vulnerable. 
Farah Zaini, Shyafiena Abdul Aziz, Nurlaila Ali, Nurul Huda Marwab

The Matrix of Land Tenure Property Right for Water Settlement Area

\section{Challenge 2: Property Right Not Legally Recognised}

Without informal land tenure, property rights are also not legally recognised by the system. Even though it is not present, R1, R2, and R3 agree that they receive assistance from the government during disasters or difficult times, particularly when it comes to repairing their property. For example, in R1 village, residents have received assistance in the last few years to repair their house roofs due to its poor condition. It was the same in R3 villages during the 2013 and 2014 fires. According to him, the incident completely destroyed nearly 30 homes. With the assistance of the state government, the victims were relocated to a more secure location.

\section{Challenge 3: Absent of Market Information Value}

The absence of market information presents another difficulty in managing the LTPR for the water settlement area. R1 concurred that in the absence of market value, property transactions in the village are conducted through mutual agreement between trusted parties. This is also true in R2's village. R1 and R2 agree that there are no disagreements regarding property transactions at the moment. However, a development plan will be implemented in the area in the future to boost the tourism and economic sectors. Without a doubt, when projects come in, investors follow. Thus, it is critical to safeguard what they have now in order to avoid future conflict. Additionally, Manaf et al. (2010) research indicates that the absence of sale and purchase agreements on the island will influence the land development process in the near future.

Challenge 4: Informal Documentation on Land Tenure and Property Right $\mathrm{R} 1, \mathrm{R} 2$, and R3 all agree that they used a similar approach to determine possession in the village. The approach of informal documentation to document the LTPR of houses in villages. The village head recorded the property's details, including the number of households, its location, size, and other characteristics. These documents have been entrusted to the district office's safekeeping. Without proper documentation, a dispute will inevitably arise during a future property transaction.

Challenge 5: Ambiguous of Land Ownership for Second Generation and Above Due to the absence of formal land tenure, the second and subsequent generations are also impacted. According to R2, a new area will be established near their village in order to relocate the villagers. However, it drew criticism from villagers, particularly the first generation. Additionally, R1 stated that the village committee has requested from the state that a new space adjacent to the village be opened and reserved for second generation residents to ensure their residential area is secure. 


\section{Challenge 6: Missing/Informal Cadastral Info}

The final obstacle is that LTPR in the water settlement area is concerned with their cadastral information. According to R3, he used a drone to map the village and forward it to the Land Office. Even though the village lacks formal cadastral information, this effort is part of legalising the village's boundary for land tenure and property rights.

\section{THE MATRIX OF LAND TENURE PROPERTY RIGHT FOR WATER SETTLEMENT AREA}

Even though the challenge and issues are not critical at the moment, they will be critical in the long run. With Sarawak's rapid planning and development, these water villages have been incorporated into the plan. Thus, based on the study's suitability, the Matrix of Land Tenure Property Rights (LTPR) for water settlement area is derived by combining the results of thematic analyses and the USAID LTPR framework. This matrix is critical because it serves as a tool for defining and recognising the LTPR for the area of water settlement.

The challenges/restraints in LTPR are linked to the interventions in this matrix using categories. Constraints or challenges in the LTPR for water settlement areas can be classified into four categories, as illustrated in Table 3. As illustrated in Figure 3, these themes will aid in the development of the matrix, as will the interventions for each challenge.

Table 3: Categorisation of LTPR Challenges in Water Settlement Areas

\begin{tabular}{|c|c|c|c|}
\hline \multicolumn{4}{|c|}{ Constraints/Challenges } \\
\hline Resource Conflict & $\begin{array}{l}\text { Insecure Land Tenure } \\
\text { and Property Right }\end{array}$ & Access to Land & $\begin{array}{l}\text { Poor Performing Land } \\
\text { Markets }\end{array}$ \\
\hline $\begin{array}{l}\text { i. Informal Land } \\
\text { Tenure } \\
\text { ii. Property Right } \\
\text { Not Legally } \\
\text { Recognised } \\
\text { iii. Informal } \\
\text { Documentation } \\
\text { on Land Tenure } \\
\text { and Property } \\
\text { Right } \\
\text { iv. Ambiguous of } \\
\text { Land Ownership } \\
\text { for Second } \\
\text { Generation and } \\
\text { Above }\end{array}$ & $\begin{array}{l}\text { i. Informal Land } \\
\text { Tenure } \\
\text { ii. Property Right Not } \\
\text { Legally Recognised } \\
\text { iii. Informal } \\
\text { Documentation on } \\
\text { Land Tenure and } \\
\text { Property Right } \\
\text { iv. Missing/Informal } \\
\text { Cadastral Info }\end{array}$ & $\begin{array}{ll}\text { i. } & \text { Ambiguous } \\
\text { of Land } \\
\text { Ownership } \\
\text { for Second } \\
\text { Generation } \\
\text { and Above }\end{array}$ & $\begin{array}{l}\text { i. Absent of Market } \\
\text { Information Value } \\
\text { ii. Informal } \\
\text { Documentation on } \\
\text { Land Tenure and } \\
\text { Property Right } \\
\text { iii. Missing/Informal } \\
\text { Cadastral Info }\end{array}$ \\
\hline
\end{tabular}


Farah Zaini, Shyafiena Abdul Aziz, Nurlaila Ali, Nurul Huda Marwab

The Matrix of Land Tenure Property Right for Water Settlement Area

\begin{tabular}{|l|l|l|l|l|l|}
\hline \multicolumn{2}{|l|}{} & \multicolumn{5}{|c|}{ Constraints/Challenges } \\
\hline & $\begin{array}{l}\text { Resource } \\
\text { Conflict }\end{array}$ & $\begin{array}{l}\text { Insecure } \\
\text { Land } \\
\text { Tenure and } \\
\text { Property } \\
\text { Right }\end{array}$ & $\begin{array}{l}\text { Access to } \\
\text { Land and } \\
\text { Natural } \\
\text { Resources }\end{array}$ & $\begin{array}{l}\text { Poor } \\
\text { Performing } \\
\text { Land } \\
\text { Markets }\end{array}$ \\
\cline { 2 - 5 } & $\begin{array}{l}\text { Awareness and } \\
\text { Empowerment }\end{array}$ & & & \\
\hline $\begin{array}{l}\text { Conflict and } \\
\text { dispute and } \\
\text { resolution }\end{array}$ & & & & \\
\hline $\begin{array}{l}\text { Legal } \\
\text { Regulatory } \\
\text { Framework }\end{array}$ & & & & \\
\hline & $\begin{array}{l}\text { Land } \\
\text { Administration } \\
\text { and }\end{array}$ & & & \\
Governance & & & & \\
\hline
\end{tabular}

Figure 3: The Matrix of Land Tenure Property Right for Water Settlement Area

According to Figure 3, challenges are addressed through four levels of intervention: community awareness and empowerment, conflict and dispute resolution, legal and regulatory framework, and land administration and governance. With this matrix, it is hoped that the LTPR for water settlement areas can be recognised.

\section{CONCLUSION}

As a result of this article, one can conclude that land tenure and property rights in the water settlement area are informal and should be formalised. Ambiguity regarding land ownership, property rights, and documentation in this area will not result in a system of good governance and land administration. Even though land disputes or conflicts are not critical, it is past time for the LTPR system to be revised to facilitate future development. LTPR must be legally recognised in order to bolster statutory rights and raise community awareness about the critical nature of having clear and transparent LTPR. In order to do so, the development of matrix of land tenure property right is essential in recognizing the LTPR for water settlement area.

\section{ACKNOWLEDGEMENT}

We would like to express our heartfelt appreciation to Ministry of Higher Education, Malaysia, Fundamental Research Grant Scheme for Research Acculturation of Early Career Researchers, RACER/1/2019/SSI11/UNIMAS//1 
for funding this research and to UNIMAS for their support.

\section{REFERENCES}

AUC, ECA, \& AfDB. (2010). Land Policy in Africa: A Framework to Strengthen Land Rights, Enhance Productivity and Secure Livelihoods. Framework and Guidelines on Land Policy in Africa. Ethiopia.

Courtney, C. A., Pomeroy, R., De Alessi, M., Adhuri, D., Yuni, C., \& Halim, A., (2017). Marine Tenure and Small-Scale Fisheries: Learning from The Indonesia Experience. Washington, DC: USAID Tenure and Global Climate Change Program and USAID Indonesia Sustainable Ecosystems Advanced Project

Denise, R. Johnson (2007). Reflection on the Bundle of Right. Vermont Law Review, 32, 247-272

FAO. (2002). Land Tenure and Rural Development. (M. Cox, Ed.) United Nations (3rd ed.). Rome, Italy: Rural Development Division.

Fischel, A. (2009). Property Rights Approach Municipal Zoning. Land Economics, 54(1), 64-81

Ismail, M. K., Siwar, C., Ghazali, R., Ab Rani, N. Z. A., \& Abdul Talib, B. (2019). The Analysis Of Vulnerability Faced By Gahai Agropolitan Participants. Planning Malaysia, 17(10). https://doi.org/10.21837/pm.v17i10.645

Manaf, A. A., Saad, S., \& Samsudin, M. (2010). Isu Pemilikan Hartanah Oleh OrangOrang Pulau Di Kawasan Darat Mersing: Kajian Kes Di Kampung Sri Bahagia, Mersing Johor. Journal of Social Sciences and Humanities, 5(2), 199-207.

Payne, G. (2000). Urban land tenure policy options: titles or rights? Habitat International, 25(June 2000), 415-429. Proceeding of the NTU PWD Seminar on Rock Caverns for Underground Space Utilization, Singapore, p23-32.

Samsudin, S. (2020). The Suitability of Institutional Arrangement and Policy Assessment Indicator in Malaysia's Land Administration System. International Journal of Academic Research in Business and Social Sciences, 10(11), 1414-1425.

Samsudin, N. A., \& Abidin Idid, S. Z. (2016). Influences Of Housing Settings and Designs in Fulfilling the Malay Residents's Social Cultures. Planning Malaysia, 14(4). https://doi.org/10.21837/pm.v14i4.152

United Nations. (2005). Land Administration in The UNECE Region: Development Trends and Main Principles. Switzerland.

USAID (2013). Land Tenure and Property Rights Framework. 3(September), 67.

Williamson, I., Enemark, S., \& Wallace, J. (2010). Land Administration for Sustainable Development Land Administration for Sustainable Development. In FIG Congress 2010: Facing the Challenges - Building the Capacity (pp. 1-16). Sydney, Australia.

Received: $19^{\text {th }}$ August 2021. Accepted: $25^{\text {th }}$ November 2021 